\title{
Social Models of Behavior of Persons Released from Prisons in Christian Rehabilitation Centers
}

\author{
H. Hladii \\ President of the NGO «Human Development Center "Intellect"», \\ PhD student of the Social Psychology of Personality Laboratory, \\ Institute for Social and Political Psychology of NAES of Ukraine, Kyiv \\ Corresponding author. E-mail: annagladiy@ukr.net
}

Paper received 02.09.18; Accepted for publication 08.09.18.

https://doi.org/10.31174/SEND-PP2018-174VI72-10

\begin{abstract}
There are presented the results of empirical study on the issue of resocialization of persons released from prisons who were proceeding rehabilitation in Christian centers (CRC). The theoretical aspects of this issue from the viewpoint of native and foreign scientific materials are analyzed. According to the empirical study runned by "Definition of predisposition to deviant behavior" by O.M. Orel and "Sense-life Orientations" by D.O. Leontiev methods, and mathematical and statistical methods at the beginning and after the rehabilitation course in CRC, it was found out the positive prosocial changes in behavior models for both men and women. For the analysis of obtained results, the statistical data processing was carried out, and the most significant characteristics of changes in the social behavior models of the respondents were selected. By discussing the results of the study, the scientific value of the research was substantiated, namely, it was first empirical study conducted on persons who have served their sentence, have become free citizens of society and have undergone a rehab course at Christian rehabilitation centers.
\end{abstract}

Keywords: persons released from prisons, rehabilitation process, social models of behavior, predisposition to deviant behavior, Christian rehabilitation centers.

Introduction. In modern Ukraine, the constant work to decrease the crime rate is conducting. In particular, there is a great work to ensure that persons released from prisons (hereinafter, PRP) are able to return to normal life. However, the increase in effectiveness of their resocialization remains an urgent task, since most of them, after serving their sentences and releasing, are again returned to prisons. Every year in Ukraine, about $35 \%$ of convicted persons are releasing from places of imprisonment. From them there are about $30-34 \%$ of those who return to prisons again (Diialnist kryminalno-vykonavchoi systemy Ukrainy, 2015-2017).

The problem of overcoming crime in the state is complicated by the fact that a certain part of antiterroristic and combat operations participants receives significant psychotraumas, becomes dissatisfied with their social problems solving and prone to apply violence and sometimes even weapons. As a result, they regularly fall under the institutions of the penitentiary system. Among the governmental and non-governmental organizations in modern Ukraine, which provide rehabilitation and resocialization services to PRP, the share of religious, in particular, Christian rehabilitation centers (hereinafter, CRC), is constantly increasing. According to the Ministry of Social Policy directory and Ukrainian Christian centers of rehabilitation representatives' information, there about 394 of such organizations are officially registered, and 289 of them are centers of various Christian denominations (Proskura, 2015, 28).

According to experts who work in these centers, the percentage of PRP, who have successfully completed the course of rehabilitation, is significantly higher than in similar secular centers. However, until now, there are no empirical socio-psychological studies of the effectiveness of the rehabilitation course conducted at CRC with persons released from prison. In recent years, the experience of PRP resocialization in the CRC has begun to attract the attention of foreign and native researchers.

The researches on the various categories of problem individuals rehabilitation (namely, PRP, who are addicted to alcohol, drugs, etc.) attracts the attention of many scientists and specialists. Thus, Yu.V. Valentik, and E. Voydylo-Osiatynska have substantiated the necessity to create the rehabilitation programs for therapeutic groups and rehabilitation centers (Valentik, 2002). The importance of attracting of different sub-societies to the problem was revealed in works of Cowan, Brazzell, Griffiths (The Social Reintegration of Offenders and Crime Prevention). The study of N. A. Solovova while elucidation of drug addicts dynamics in the process of rehabilitation have shown positive changes and creation of new behavioral patterns (Solovova, 2009).

In particular, V.V. Proskura analyzed the role of the church in the resocialization of the convicted persons and considered the technology of social adaptation for men released from prisons (Proskura, 2015). The features of addicts' and alcoholics' rehabilitation in the CRC, as well as their rehabilitation models, are considered in the collective work of V. M. Zhukovskyi, O. I. Klymyshyn, and T. Lozynska (Zhukovskyi et al., 2014).

By native and foreign scientific material analyzing it was concluded that:

- the rehabilitation process is a necessary step for persons released from prisons, especially for those who have addictions, - it reduces the repetitions in returning of PRP to the institutions of penitentiary system;

- in the process of successful rehabilitation there are changes in the direction of positivity, - it reduces the number of relapses in violations of legal norms and laws.

The purpose of the article is empirical study of PRP's models of social behavior, both men and women, at the beginning and in the end of the rehabilitation course in CRC. Accordingly, the objectives of the study are:

1. To carry out an empirical analysis of the asocial behavior patterns of the rehabilitation course male and female participants to find out their possible changes.

2. To determine the existence of the prosocial characteristics emergence in the process of rehabilitation of male and female PRP in the CRC.

3. To find out the nature of changes in the social mod- 
els of behavior of male and female PRP in the CRC.

Research methods. The works of the Social Psychology of Personality Laboratory of the Institute for Social and Political Psychology of the NAES of Ukraine have explored the precondition of person's behavior by hisher main practices, as well as changes in the person's behavior patterns as a result of hisher practices and lifestyle changing (Lazorenko, 2007, Tytarenko et al., 2014).

As we assume the PRP are characterized by the social practices that have been formed on the basis of asocial behavior models. To change these practices, it is necessary to achieve changes in social models of behavior from asocial to prosocial. This, in fact, is the task of the rehabilitation course. The term "model of behavior" ("behavioral model", "pattern of behavior") is used by such experts as A. Bandura, R. Merton, D. Myers and others. In our study, we use the notion of "social behavior", which was justified by Russian sociologist S.A. Mitriushyn as "an active form of the social sphere transformation, as a conscious motivated act of an individual or a social group that arises to meet certain needs and to achieve certain goals".

We've operationalized the "social model of behavior" concept using the "Definition of predisposition to deviant behavior" method by O.M. Orel and "Sense-life Orientations" method by D.O. Leontiev. The method by O.M. Orel was developed to evaluate deviant behavior of adolescents. In the course of our work, we've adapted it for adults.

By O.M. Orel's method we were determining the level of asocial characteristics among PRP, and by D.O. Leontiev's method we were finding out their prosocial characteristics. We've interviewed respondents according to these methods at the beginning of the rehabilitation course and after its completion. The rehabilitation course duration was one year.

On the basis of comparison of the evaluated characteristics at the beginning and after the completion of the rehabilitation course in CRC and the definition of changes in these characteristics in the direction of their prosociality, we were concluding if there were any changes in behavior patterns from asocial to prosocial ones. As a defining "practical" criterion for these changes, we've used the absence of asocial behavior recurrence of rehabilitants during their stay in the CRC.

According to the selected methods, three main indicators in the levels of characteristics manifestation are foreseen (percentage from $0 \%$ to $100 \%$ ). The high level reffers to the high degree of characteristics manifestation, the medium one is about its widely accepted manifestation, and the low one reffers to the insignificance of its manifestation among PRP. According to the changes in these characteristics among PRP in the process of their rehabilitation, three subgroups of the studied subjects were identified and the corresponding dynamics in these subgroups was determined.

As the main personal characteristics of behavior, according to the "Definition of predisposition to deviant behavior" method by O.M. Orel, there are offered the following keys: orientation on social desirability; propensity to overcome norms and rules; propensity to addictive behavior; propensity to destructive behavior; propensity to aggression and violence; volitional control of emotional reactions; propensity to delinquent behavior. The full analysis on them is presented in our dissertation. In order to distinguish the most significant characteristics in changes of the model of respondents' social behavior, we've conducted an expert study among the CRC heads and ministers. The expert study have covered 5 men aged 38 to 45 years old, with CRC experience from 2 to 12 years, and 5 women aged 41 to 63 years, work experience from 2 to 10 years. Specialized higher education had one woman and two men. Other participants graduated from the Christian School of Leadership.

According to the experts' opinion, the most significant keys in O.M. Orel's method were: orientation on social desirability; propensity to overcome norms and rules; propensity to addictive behavior; volitional control of emotional reactions. We must note that "orientation on social desirability" indicator in the original method is considered as an auxiliary one to measure the readiness of the respondents to represent themselves in the most favorable way in terms of social desirability. Taking into account the specifics of PRP rehabilitants, we interpret this scale not so much as their attempts to present themselves in a better light than they are, but as a level of their subjective desire and intentions to adapt to the new prosocial way of life.

In order to operationalize the social model of PRP behavior concept using the "Sense-life Orientations" method by D.O. Leontiev, the following characteristics were taken: life benchmarks; goals in life; process of life, emotional saturation of life; life effectiveness, selfrealization; "I" locus of control; life locus of control. As we've fully researched them in the dissertation, in the article it is presented the results for the most important in the experts' opinion keys: the process of life, the emotional saturation of life; life effectiveness, selfrealization; "I" locus of control; life locus of control.

Also, for the analysis of the obtained results and the selection of statistically significant differences between male and female groups, we've used the following mathematical and statistical methods: descriptive mathematical statistics; statistical comparison of mean values (Pearson $\chi^{2}$ criterion); analysis of the methods' reliability and the form of data distribution (according to the Kolmogorov-Smirnov criterion); U-Mann-Whitney criterion, z-Wilcoxon criterion. The data was processed using the IBM SPSS Statistics software package (20.0 version).

The total sample included 70 respondents, 35 men, 2647 years old, and 35 women, 23-49 years old. The research was carried out at CRC and NGOs communities directly involved in the rehabilitation of PRP in Kyiv, and Kyiv, Cherkassy, Chernihiv, and Poltava regions from January 2013 to December 2015.

Research results. At the beginning of the study the "Definition of predisposition to deviant behavior" method by O.M. Orel showed that all three indicators of the key "orientation on social desirability" in male subgroup had approximately same frequency: $31.4 \%$ of persons with a low level, $37.1 \%$ - medium level, 31.4\% - high level. At the end of rehabilitation these indicators changed as follows: the number of people with a low level significantly decreased to $8.6 \%(-22.8 \%)$, the amount of 
respondents with medium level rised to $40.0 \%(+2.9 \%)$, but the high level indicators also increased significantly to $51.4 \%(+20 \%)$.

In female subgroup at the beginning of the study there were $2.9 \%$ low-level respondents, medium level - 20\%, high level $-77.1 \%$. At the end of rehabilitation course these indicators have changed significantly. Thus, the number of women with a low level increased slightly to $8.6 \%(+5.7 \%)$, the medium level doubled to $40 \%$ (+ $20 \%$ ), the high level on the contrary decreased significantly to $51.4 \%(-25.7 \%)$.

The indicators of propensity to overcome norms and rules show the extent of the predisposition to deny the generally accepted norms and values, patterns of behavior. At the beginning of the study $80 \%$ of men showed low levels of this indicator, $20 \%$ - showed medium level. At the end of the study the indicators of the low level decreased to $68.6 \%(-11.4 \%)$, and the medium level increased to $31.4 \%(+11.4 \%)$. Instead, the indicators of $97.1 \%$ of women with low levels and $2.9 \%$ - with medium levels remained unchanged. High levels in men and women were absent.

According to the results of the "predisposition to addictive behavior" study, the medium levels in men slightly decreased from $20 \%$ to $14.3 \%$ (-5.7\%). Instead, the low level has increased - from $80 \%$ to $85.7 \%$ (+ $5.7 \%)$. In women, these indicators remained unchanged: $97.1 \%$ of respondents with the low level, and $2.9 \%$ - with medium level.

The results of the "volitional control of emotional reactions" study which is reversible, found that in men the amount of low levels decreased from $5.9 \%$ to $2.7 \%$ ($2.9 \%$ ), also the medium level decreased from $31.4 \%$ to $17.1 \%(-14.3 \%)$, while the high level indicators increased from $65.7 \%$ to $77.1 \%(+11.4 \%)$. Such changes indicate that $77.1 \%$ of men started to believe that they can control their emotions while staying in CRC. In women, the low level was absent, the medium level has decreased from $28.6 \%$ to $17.1 \%(-11.5 \%)$, and high level has increased from $71.4 \%$ to $82.9 \%(+11.5 \%)$.

Using the Wilcoxon criterion, we've compared male and female samples at the beginning and in the end of the study. In men there were revealed the significant changes in the "orientation on social desirability" indicator: coefficient $\mathrm{z}$ was equal to 2,627 with statistical significance $\mathrm{p} \leq 0.01$. High significance shows that under the pressure of new behavioral patterns assimilation, old patterns of behavior are slowed down and go out of being. In women, who had been continuing the rehab program, any significant changes were found for these indicators. This reveals that the psycho-emotional state of the participants in the rehabilitation course had not yet reached relativistic stability and they were having difficulties in their behavior managing and controlling.

In order to operationalize the social model of behavior of PRP concept using the "Sense-life Orientations" method by D.O. Leontiev, the following characteristics were taken: life benchmarks; goals in life; process of life, emotional saturation of life; life effectiveness, selfrealization; "I" locus of control; life locus of control. We fully researched them in the dissertation. In this article we are presenting the results for the most important keys according to the expert survey: the process of life, the emotional saturation of life; life effectiveness, selfrealization; "I" locus of control; life locus of control.

The "process of life, emotional saturation of life" item shows what life lives a person in the present time, and if he/she lives by past memories or by dreams and plans for the future. This data shows that the low level of indicators in male subgroup in the end of rehabilitation course was reduced from $74.3 \%$ to $57.1 \%(-17.2 \%)$, the medium levels increased from $8.6 \%$ to $11.4 \%(+2.8 \%)$, while the high level increased from $17.1 \%$ to $31.4 \%(+14.3 \%)$.

At the beginning of the study, the low level performed in $65.7 \%$ of women, the medium level - in $2.9 \%$, and a high level - in $31.4 \%$ of female respondents. After the rehabilitation course, the low level has dropped almost twice to $28.6 \%(-37.1 \%)$, the medium level has risen to $11.4 \%(+8.5 \%)$, and the high-level data increased almost twofold to $60 \%(+28.6 \%)$. This testifies the fact that during the rehabilitation course both in men and women there is an increase in subjective satisfaction with the process of life and increase in the sense of the richness of life. At the same time in women these indicators are expressed brighter $(\mathrm{z}=3.111$ at $\mathrm{p} \leq 0,01)$, there is an increase in the emotional background of life. They smile more often, they are actively involved in the work of the center. However, as practice shows, women more likely than men tend to cry and experience emotional frustration. This points to the lack in a certain amount of them of volitional control of their needs and sensory affections. As female participants personally testify, sometimes they just want to cry and nothing more.

The "life effectiveness, self-realization" characteristic verifies the respondents' self-esteem of the lived part of life, if it was effective and what sense it takes for the rehabilitant. The analysis shows that at the beginning of the rehabilitation course there were $82.9 \%$ men with low level of this item, $2.9 \%$ - with medium one, and $14.3 \%$ with high level. In the end of rehabilitation course, these indicators changed as follows: the number of men with a low level decreased almost twice to $45.7 \%(-37.2 \%)$, the medium levels reached $20.0 \%(+17.1 \%)$, and high levels increased to $34.3 \%(+20 \%)$. In women at the beginning of the course there were $60.0 \%$ of them low level, $8.6 \%$ were - with medium level, and $31.4 \%$ - with high level. In the end of the rehab course there were $28.6 \%$ of women with a low level, and those women $(-31.4 \%)$ who were in this group at the beginning moved to other groups. Due to such changes, the medium level reached $20,0 \%$ of women $(+11,4 \%)$, and high level increased to $51,4 \%(+20,0 \%)$. Thus, by the end of the course, male and female high levels increased to $20 \%$. This suggests that the vast majority of rehabilitants believe that their previous lifestyle and its outcomes are not worthy of appreciation, and they tend to evaluate their new life experiences in CRC positively and fairly high.

"I" locus of control item characterizes the individual's responsibility for own life decisions, for the acceptance of common values, rules, norms, and laws. Analysis of the male respondents' locus of control showed that at the beginning of the rehab course there were $45.7 \%$ persons with low level, $31.4 \%$ - with medium level, $22.9 \%$ - with high level. At the end of the rehabilitation course, these indicators changed as follows: the number of men with a low level decreased almost twice to $22.9 \%(-22.8 \%)$, the 
medium levels decreased to $28.6 \%(-2.8 \%)$, and high levels reached $48.6 \%(+25.7 \%)$.

In female subgroup, there were $22.9 \%$ of respondents with low level individuals of "I" locus of control, $2.9 \%-$ with medium level, and $74.3 \%$ - with high level. In the the end of the rehab course there were $2.9 \%$ of women with low level of this indicator. Those women who were in this group at the beginning moved to other subgroups $(20.0 \%)$. Due to the rehabilitation course, the medium levels were reached in $8.6 \%$ of women $(+5.7 \%)$, and high levels - in $88.6 \%(+14.3 \%)$.

The "life locus of control" indicators at the beginning of the course in male subgroup were as follows: $85.7 \%$ with low level, $8.6 \%$ with medium level, $5.7 \%$ with high level. In the end of rehabilitation, these indicators changed as follows: the number of persons with low level decreased to $54.3 \%(-31.4 \%)$, the medium level amounted $28.6 \%$ of respondents $(+20.0 \%)$, and high level $-17.1 \%$ $(+11.4 \%)$. In women at the beginning of the course low levels constituted $57.1 \%$, medium $-14.3 \%$, high $-28.6 \%$. In the end of rehab course, the low level decreased to $22.9 \%(-34.2 \%)$. Some women from this group moved to other groups. The medium levels have reached $22.9 \%$ of respondents $(+8.6 \%)$, high levels $-54.3 \%(+25.7 \%)$.

In men, the difficulties in controlling of their lives is more pronounced $(\mathrm{z}=2.230, \mathrm{p} \leq 0.05)$, and women are more included in the process of their lives controlling $(\mathrm{z}=$ $2,740, \mathrm{p} \leq 0.05)$.

Statistical analysis by Wilcoxon's criterion in male subgroup by "life effectiveness, self-realization" key showed $\mathrm{z}=-2,376$ with statistical significance $\mathrm{p} \leq 0.05$, which characterizes weak volition for self-realization and self-control. And by the "I" locus of control item, the zcoefficient is equal -2.707 at statistical significance $\mathrm{p} \leq 0.01$, which shows men's intention to control their lives. It is about that they must solve their urgent sociolegal issues with law enforcement officials while starting the course of rehabilitation in the CRC. Namely, they have to draw up the necessary certificates, documents on record-keeping, to clarify their relations with the tax inspectorate (upon documents, reports, tax payments) and with banks (identification of loans, etc.). By the beginning of the rehab course, they start to solve their vital tasks on health restoration. During the course participants register in the hospital and receive prophylactic medical services. These first steps in establishing a new social life allow to strengthen their self-esteem and self-confidence, to take some responsibility for their life. By interaction with the official representatives of the relevant social services, they acquire skills and experience of prosocial communication. Women are more active in accepting the new way of life proposed in CRC. Many years of family ties lack, material and moral support lack, low professional level, or profession absence - all these factors suggest that, it is difficult for women who have released from prisons and have become members of Christian rehabilitation centers to acquire skills to manage their lives.

The "orientation on social desirability" key in the "Definition of predisposition to deviant behavior" method by O. M. Orel indicated a significant increase in men's intent to master the new way of life, practiced in CRC. A significant part of women, who at the beginning of the course exaggerated their adherence to the norms and rules offered at the CRC, after the practical course has become more realistic towars these rules. The low indicators in the "tendency to overcome norms and rules" key has shown that men were more inclined to resist new norms and rules (the low levels has increased to the medium ones), and women were more stable in their adherence to new norms and rules of life in the CRC.

The absence of high-level indicators for both men and women in the "tendency to addictive behavior" key suggests that they are prone to the prosocial model of behavior. The auspicious environment in the center, group and individual conversations, and trainings are helpful.

The research results on the "volitional control of emotional reactions" key have shown an increase in high indicators in men and women; they have become more focused and more confident in their prosocial life orientation, and their model of behavior have become more prosocial.

However, we must add to these data the results of the author's questionnaire on addictions, which has shown the high levels of alcohol and drug addiction both in men and women before the rehabilitation course. In men, there were $54 \%$ of participants with alcohol addiction was, $75 \%$ - with drug addiction; in women, 37\% -with alcohol addiction, and $54 \%$ - with drug addiction. This suggests the differences between the rehabilitants' desires and the actual formation of a new addiction-free behavior model. Favorable conditions of staying in CRC, friendly environment for rehabilitation, in which there are any stressful factors of criminal life, any alcohol and drugs abuse, are not likely to provoke relapses of asocial behavior. However, in a certain part of rehabilitants on the resocialization stage after completing their stay in the CRC there cases of recurrence of addictive behavior are observed.

According to the "Sense-life Orientations" method by D.O. Leontiev the indicators on keys "process of life, emotional saturation of life"; "life effectiveness, selfrealization"; "I" locus of control; "life locus of control" have also changed. Both men and women after the rehabilitation course showed increases in subjective satisfaction with the process of life and the sense of life richness. Also, these data indicate that the formation of a social behavior pattern in both men and women is unstable, PRP are preparing to leave the CRC and are looking for effective solutions to their vital life tasks.

The Pearson criterion $\chi^{2}$ showed that there are no statistically significant differences in data obtained from rehabilitants at the beginning and in the end of the research. This may indicate the existence of inhibitory factors which prevent the formation of certain characteristics of new prosocial models of behavior. This also explains the fact that a certain part of the rehabilitants at the CRC were not able to complete the course and leave the center. But we've conducted the first study on people who have been released from prisons, have become the members of a rehabilitation course, and have successfully completed it. After the empirical study it was revealed the changes in behaviors and characteristics of new models of positive social behavior emergence.

Conclusions. As a result of the study using the "Definition of predisposition to deviant behavior" method by O.M. Orel, "Sense-life Orientations" method by 
D.O. Leontiev, and the above-mentioned mathematical and statistical methods there were found the prosocial changes in behavior models of PRP who took one-year rehabilitation course in CRC.

According to the O.M. Orel's method, the key indicators which characterized the asocial behavior patterns of studied men have changed as follows: the amount of low levels decreased from $60.0 \%$ to $56.4 \%$, the high levels decreased from $48.6 \%$ to $35.7 \%$. Medium levels also decreased on average from $37.1 \%$ to $32.4 \%$. Women have achieved somewhat bigger success. Their low levels have increased from $52.2 \%$ to $66.1 \%$, medium levels have rised from $14.3 \%$ to $15.1 \%$, and the high levels have dropped from $52.3 \%$ to $48.6 \%$. This indicates a decrease in rehabilitants' asocial behavior characteristics and increase in their prosocial orientation. At the same time, the prosocial character of behavior in women is more pronounced than in men.

By the D.O. Leontiev's method in men, the indicators of high levels of prosocial model of behavior have increased on average from $14.3 \%$ to $33.3 \%$, and medium levels has risen from $11.4 \%$ to $17.6 \%$. In women, high levels have increased on average from $44.8 \%$ to $64.3 \%$, and medium levels - from $6.7 \%$ to $13.8 \%$. Correspondingly, low-level indicators have decreased in both subgroups. These data indicate the effectiveness of the rehabilitation course on the inhibition of antisocial behavior patterns of CRC rehabilitants and, accordingly, point to the formation and strengthening of their prosocial behavior models. At the same time, according to the "practical" criterion of the rehabilitation effectiveness, during their stay in the CRC, they had no recurrence of legal norms and laws violations, as well as any neglect on rules of coexistence in CRC.

\section{REFERENCES}

1. Valentik, Yu.V. (2002). Reabilitacionnye centry «Casa Famiglia Rosetta»: 20-letnij opyt raboty [Rehabilitation centers "Casa Famiglia Rosetta»: 20 years of work experience]. Moskow: Airis-Press. (ru)

2. Hladii, H.I. (2015). Modeliuvannia novoho zhyttia za dopomohoiu pozytyvnykh praktyk [Modelling of new life by positive practices]. Nowoczesna edukacja: filozofia, innowacja, doświadczenie [Modern education: philosophy, innovation and expierence]. Łódź : Wydawnictwo Naukowe Wyższej Szkoły Informatyki i Umiejętności, 4, 15-20. (ua, pl)

3. Diialnist kryminalno-vykonavchoi systemy Ukrainy u 2015, 2016, 2017 rotsi. Statystychnyi ohliad. [Activities of the Ukrainian Criminal Execution System in 2015, 2016, 2017. Statistical Review]. Retrieved from http://ukrprison.org.ua/articles/1453132032. (ua)

4. Anichyn, Ye. M., Dykan, Z. V., Siedykh, S. M. (ed. 2014). Dopomoha narkozalezhnym $v$ Ukraini: dovidnyk reabilitatsiinykh tsentriv [Assistance to drug addicts in Ukraine: Directory of Rehabilitation Centers]. Kyiv: «Mizhnarodnyi Alians z VIL/SNID v Ukraini». (ua)

5. Lazorenko, B. P. (2007). Problemna molod: shliakhy samozdiisnennia [Problem youth: ways of self-realization]. Kyiv: Pedahohichna dumka. (ua)

6. Informatsiia pro vykonannia Planu zakhodiv z realizatsii Kontseptsii sotsialnoi adaptatsii osib, yaki vidbuvaly pokarannia u vydi pozbavlennia voli na pevnyi strok, do 2015 roku, zatverdzhenoho rozporiadzhenniam Kabinetu Ministriv Ukrainy vid 01.07.2009 [Information on the Action Plan for the implementation of the Concept of Social Adaptation of Persons serving a sentence in the form of imprisonment for a certain period until 2015, approved by the Cabinet of Ministers of Ukraine from 01.07.2009]. Retrieved from http://www.mlsp.gov.ua/labour/control/uk/publish/article;jses sionid=D508166F7095B9663AB81CB6250954E7.app1?art_i d=165167\&cat_id=34941. (ua)

7. Zhukovskyi, V. M., Klymyshyn, O. I. et. al (2014). Pobudova systemy reabilitatsii adytyvnykh osib, na osnovi khrystyianskoi psykholohii [Construction of a system of rehabilitation of addicts, based on Christian psychology]. Ostroh: Vydavnytstvo Natsionalnoho universytetu «Ostrozka akademiia». (ua)

8. Proskura, V. V. (2015) Rol tserkvy u resotsializatsii zasudzhenykh do pozbavlennia voli [The role of the church in the resocialization of those who sentenced to imprisonment]. Sotsialna polityka i sotsiolohiia [Social policy and sociology], 2(53), 17-22. (ua)

9. Pro sotsialnu adaptatsiiu osib, yaki vidbuvaly pokarannia u vydi obmezhennia voli abo pozbavlennia voli na pevnyi strok: Zakon Ukrainy vid 17 bereznia 2011 roku, N 3160-VI [On the social adaptation of persons serving a sentence in the form of restraint of liberty or imprisonment for a specified period: Law of Ukraine dated March 17, 2011, No 3160-VI] (2011). Vidomosti Verkhovnoi Rady, 38, 380- 383. (ua)

10. Solovova, N. A. (2009). Dinamika lichnostnyh osobennostej narkozavisimyh $\mathrm{v}$ processe reabilitacii [Dynamics of personal characteristics of drug addicts in the process of rehabilitation]. Retrieved from http://www.dslib.net/psixologia-razvitja/dinamikalichnostnyh-osobennostej-narkozavisimyh-v-processereabilitacii.html. (ru)

11. The Social Reintegration of Offenders and Crime Prevention. Retrieved

from https://www.publicsafety.gc.ca/cnt/rsrcs/pblctns/sclrntgrtn/index-en.aspx\#s3. (ru)

12. Tytarenko, T. M., Kochubeinyk, O. M., Cheremnykh, K. O. (2014). Psykholohichni praktyky konstruiuvannia zhyttia v umovakh postmodernoi sotsialnosti [Psychological practices of constructing life in the conditions of postmodern sociality]. Kyiv: Milenium. (ua) 